FILOLOGIJA 73, Zagreb 2019.

UDK 81`374.73:81`373.72

DOI https://dx.doi.org/10.21857/moxpjhgwpm Pregledni članak

Rukopis primljen 27. V. 2019. Prihvaćen za tisak 23. IX. 2019.

Ivana Filipović Petrović

Zavod za lingvistička istraživanja

Hrvatska akademija znanosti i umjetnosti

Ulica književnika Ante Kovačića 5, HR-10000 Zagreb

ifilipovic@hazu.hr

Jelena Parizoska

Učiteljski fakultet

Sveučilište u Zagrebu

Savska cesta 77, HR-10000 Zagreb

jelena.parizoska@ufzg.hr

\title{
KONCEPTUALNA ORGANIZACIJA FRAZEOLOŠKIH RJEČNIKA U E-LEKSIKOGRAFIJI
}

$\mathrm{U}$ organizaciji građe $\mathrm{u}$ jednojezičnim frazeološkim rječnicima hrvatskoga jezika dominira abecedno ustrojstvo, dok se u leksikografiji nekih drugih europskih jezika poput engleskoga i ruskoga primjenjuje i konceptualni pristup te se frazemi grupiraju u zajednička tematska polja. Nove mogućnosti za leksikografiju donijeli su e-rječnici koji omogućuju uključivanje podataka o konceptualnoj povezanosti jezičnih jedinica. Budući da su u e-leksikografiji prostorna ograničenja dokinuta, pri konceptualnoj organizaciji frazeološke građe javlja se pitanje po kojim kriterijima treba povezati frazeme srodnih značenja i koliki broj jedinica zajedno grupirati unutar određene teme. Cilj je ovoga rada pokazati mogućnosti organizacije građe u mrežnome Frazeološkom rječniku hrvatskoga jezika koji je u izradi, a uključuje i konceptualni ustroj. Točnije, pokazat ćemo da način konceptualne organizacije može varirati pa frazeme povezuje određeni koncept (šira organizacija) ili su grupirani u specifične značenjske podskupine (uža organizacija). Tako se ujedno propituje koje su prednosti i nedostaci pojedinih načela leksikografske obrade frazema u e-rječniku. 


\section{Uvod}

Organizacija leksičke građe $u$ jednojezičnim rječnicima $u$ pravilu je abecedno ustrojena, s namjerom da korisnik brzo i jednostavno pristupi onome što traži, a najčešće je to jedna tražena jedinica. Dominacija abecedne leksikografije jaka je toliko da se abecedni poredak natuknica često shvaća kao neizostavno obilježje rječnika (Landau 2001). Međutim, postavlja se pitanje postoje li neke korisničke potrebe koje bi se bolje mogle ispuniti alternativnim načinom organizacije riječi u rječniku (vidi npr. Jackson 2003:145-160). Takav je zaokret potaknut dvjema pojavama: strujanjima u lingvistici unazad 40-ak godina koja su u fokus dovela leksikon i njegovu povezanost s principima funkcioniranja ljudskog uma te razvojem elektroničke leksikografije. Premda je abecedna organizacija dominirala tijekom povijesti leksikografije, paralelno su se sastavljali tematski ustrojeni rječnici (tezaurusi). ${ }^{1}$ Autori takvih rječnika smatrali su da je konceptualna organizacija primjerenija načinu na koji um organizira vlastite ideje i riječi (za detaljnije opise tipologije konceptualne leksikografije vidi McArthur 1986; Nikolić-Hoyt 2004). Kada se govori o razlikama između abecedno ustrojenog i konceptualno ustrojenog rječnika, ističe se da korisnici polazeći od riječi u rječniku tragaju za njezinim značenjem, a u tezaurusu polaze od pojma, tragajući za riječima (Geeraerts 1989).

Konceptualni ustroj važan je i za višečlane jezične jedinice. Kad je riječ o frazemima, neki specijalizirani rječnici korisnicima nude upravo to: tematsku organizaciju kako bi im omogućili da izraze neku ideju. Na primjer, u predgovoru tematskome indeksu Collinsova frazeološkog rječnika engleskoga jezika (Collins COBUILD Idioms Dictionary 2002) navodi se čemu taj indeks služi: ako korisnik traži frazeme koje povezuje određena tema, ako želi naći engleski frazem koji je po značenju sličan nekom frazemu u njegovu jeziku i ako se ne može sjetiti oblika nekog frazema, ali $\mathrm{mu}$ je poznato njegovo značenje. $U$ dvjema velikim leksikografskim tradicijama - engleskoga i ruskoga jezika - dva su osnovna načina konceptualne organizacije jezične građe $u$ tiskanim frazeološkim rječnicima. Jedan je isključivo konceptualni ustroj, a imaju ga tematski frazeološki rječnici (Spears 1998), rječnici frazeoloških sinonima (Bierich-Mokienko-Stepanova 2001) i frazeološki tezaurusi (Baranov-Dobrovol'skij 2007). Drugi je način kombinacija abecednog i konceptualnog ustroja. Tako jednojezični frazeološki rječnici engleskoga jezika sadrže posebne odjeljke s fraze-

1 U većini se tipologija rječnika način na koji je organiziran korisnički pristup podacima - abecedno ili tematski (konceptualno) - javlja kao jedan od razlikovnih kriterija (Ščerba 1974:265-304; Landau 2001; Béjoint 2010). 
mima grupiranim $\mathrm{u}$ teme (engl. themes ili topics) kao što su problem, ljutnja, sreća, uspjeh, razumijevanje itd. Među tiskanim ruskim frazeološkim rječnicima abecedno-konceptualni ustroj nalazimo u Rječniku poredbenih frazema ruskoga jezika (Ogoljcev 2001), u kojemu se za svaki frazem na kraju natuknice bilježe njegovi sinonimi i antonimi. S druge strane, jednojezični frazeološki rječnici hrvatskoga jezika imaju samo abecedni poredak (Matešić 1982; Menac - Fink Arsovski - Venturin 2003, 2014). Nedostaci isključivo abecednog ustroja frazeološkog rječnika ogledaju se ponajprije u tome što su značenjski bliski frazemi fizički udaljeni jedni od drugih ako ne dijele sastavnice koje su abecedno blizu i zapravo nema načina da ih korisnici povežu (npr. fali daska u glavi komu i najeo se ludih gljiva tko). ${ }^{2}$

Nove i dodatne mogućnosti za leksikografiju općenito - a konkretno za izradu frazeoloških rječnika - otvorilo je digitalno doba. One se ogledaju prvenstveno $u$ tome što $u$ e-rječniku nema prostornog ograničenja kao $u$ tiskanoj knjizi i moguća je drukčija organizacija natuknice koja uključuje hipertekstove, odnosno poveznice. Stoga e-rječnici omogućuju da se u leksikografsku obradu uključe relevantni konceptualni odnosi kojima se putem poveznica može jednostavno pristupiti. Jedan je takav leksikografski projekt mrežni Frazeološki rječnik hrvatskoga jezika koji je u izradi. ${ }^{3}$ Planirani konačni proizvod projektnoga rada prvi je izvorno elektronički, korpusom vođen frazeološki rječnik hrvatskoga jezika u otvorenom pristupu, temeljen na teorijskim načelima suvremene korpusne i funkcionalne leksikografije. U skladu s time, provode se korpusna istraživanja frazema, analiziraju rezultati čestotnosti i karakterističnosti oblika, značenja i upotrebe frazema na temelju kojih se oblikuje leksikografska obrada. Zahvaljujući neograničenom prostoru e-rječnika i mogućnostima alata u kojemu se rječnik izrađuje, ${ }^{4}$ natuknica u tome rječniku između ostalog u posebnim odjeljcima sadržava informacije o specifičnoj upotrebi (engl. usage notes), karakteristične za korpusno utemeljene rječnike (detaljnije o metodologiji izrade toga rječnika vidi Filipović Petrović 2018:138-149). Također, u tome je rječniku građa organizirana tako da se na kraju natuknice navode frazemi koji su značenjski povezani s onim u natukničkome liku. Budući da su u njemu (kao u svakom e-rječniku) prostorna ograničenja dokinuta, javljaju se pitanja koja se tiču metodologije konceptualne organizacije frazema,

2 Svojevrsni tematski ustroj imaju dvojezični englesko-hrvatski i hrvatsko-engleski frazeološki rječnici (Bendow 2006, 2009). U njima se na kraju natuknica daju frazemi značenjski povezani s onim u natukničkome liku, ali to se naznačuje posredno, oznakom usporedivo.

3 Projekt se odvija u Zavodu za lingvistička istraživanja Hrvatske akademije znanosti i umjetnosti.

4 Vidi Měchura 2017. 
na primjer koliko značenjski povezanih frazema uključiti u natuknicu i po kojim kriterijima. Konkretno, postavlja se pitanje treba li korisniku unutar natuknice ponuditi sve frazeme koji su značenjski povezani (npr. sve koji se odnose na ljutnju, sreću i slično) ili poveznica među frazemima treba biti specifičnije značenje?

Cilj je ovoga rada pokazati mogućnosti organizacije građe u mrežnome Frazeološkom rječniku hrvatskog jezika koji je u izradi, a uključuje i konceptualni ustroj. Točnije, pokazat ćemo da način konceptualne organizacije frazema može varirati: jedinice može povezivati određeni koncept (na primjer, teška situacija) pa je riječ o široj konceptualnoj organizaciji ili one mogu predstavljati specifične značenjske podskupine (na primjer, 'ljutit' odnosno 'naljutiti se') pa je riječ o užoj konceptualnoj organizaciji. To je izravno vezano uz značenjska i strukturna obilježja frazema te njihovu upotrebu.

Rad započinjemo osvrtom na ustroj rječnika u eri e-leksikografije te na suodnos abecedne i konceptualne organizacije u e-rječnicima. Nakon toga dajemo kratak pregled načina tematske organizacije frazema u engleskim i ruskim tiskanim i mrežnim rječnicima kao primjerima dobre prakse. Zatim opisujemo metodologiju i kriterije grupiranja frazema u značenjske skupine u mrežnome Frazeološkom rječniku hrvatskog jezika te na primjerima pokazujemo mogućnosti konceptualnog ustroja građe $u$ tome rječniku. Na kraju rada slijedi zaključak.

\section{Ustroj rječnika u eri e-leksikografije $\mathrm{e}^{5}$}

Prednosti elektroničkog medija naširoko su poznate. Najprije, prostor: mogu se pohraniti ogromne količine informacija, što je jedan od razloga zašto su enciklopedije postale elektroničke istog trenutka kada je tehnologija to omogućila. Zatim, mogu se dodavati nove riječi, stavljati poveznice na mrežne stranice ili druge dokumente. U e-rječniku moguće je izabrati kakav pristupačan grafički oblik teksta, moguće je sve kratice iz tiskanih inačica dati u punom obliku, novi prozorčići unutar natuknice mogu otvarati nove i dodatne podatke, potpunu fleksiju za svaku riječ, etimologiju, sinonimiju i tako dalje. ${ }^{6}$ Konačno, u e-rječniku korisnik ne mora po-

5 Za pregled hrvatske e-leksikografije vidi Štrkalj Despot i Moehrs 2015; Štrkalj Despot i dr. 2019.

6 Tako se, na primjer, u mrežnome Kolokacijskome rječniku suvremenog slovenskoga jezika (https://viri.cjvt.si/kolokacije/slv/) daju podaci o čestoti upotrebe pojedinih kolokacija, a u tezaurusu slovenskoga jezika (https://viri.cjvt.si/sopomenke/slv/) klikom na pojedine jedinice dobivaju se primjeri upotrebe iz korpusa Gigafida. 
sezati za svojim znanjem abecede jer pristup građi ne ovisi o njoj - sadržaj se uglavnom može pretraživati po bilo kojoj riječi, dijelu riječi, čak i na pogrešno utipkane kombinacije slova mogu se ponuditi opcije. U nekim su e-rječnicima sustavi za pretragu dovoljno razrađeni da korisnik može zatražiti sva pojavljivanja neke riječi unutar natuknica, sve definicije koje sadrže određenu riječ i slično. Tako su ustrojeni mrežni jednojezični rječnici engleskoga jezika. Na primjer, u natuknici imenice hand ('ruka') u rječnicima Collins English Dictionary i Macmillan Dictionary nalaze se poveznice na složenice i višerječnice koje sadrže oblik hand (npr. imenska sintagma free hand 'odriješene ruke', prijedložni izraz at hand 'pri ruci', frazni glagol hand in 'predati koga, što' te pridjev left-hand 'lijevi'). U natuknici za istu imenicu u Longmanovu se mrežnome rječniku na početku natuknice daje tvorbena porodica riječi te se navode imenica handful 'nekolicina, šačica', pridjevi handy 'praktičan' i underhand 'nepošten', glagol hand 'uručiti, pružiti' te prilog handily 'nadohvat'.

U eri e-rječnika ujedno se promijenio stav prema informaciji - više je ne moramo pamtiti jer joj se brzo i lako možemo vratiti i opet je koristiti (usp. Béjoint 2010). Predviđa se da će e-rječnici ići u smjeru prilagodbe korisniku i personalizaciji i postati kolekcije leksičkih izvora koje će korisnici prilagođavati svojim potrebama (Atkins-Rundell 2008). Sučelja se dizajniraju na način da funkcionalno prikazuju rječnički sadržaj, na tragu funkcionalne teorije leksikografije danske Aarhuške škole ${ }^{7}$ (Leroyer 2007; Nielsen-Mourier 2007). Funkcionalna leksikografija podrazumijeva da je proizvodnja rječnika vođena korisničkim potrebama s ciljem pružanja znanja potrebnog za komunikaciju u određenim situacijama u kojima se korisnik može naći (Fuertes-Olivera 2009). Posebna se pažnja usmjerila na mogućnosti pružanja različitih dodatnih leksičkih informacija, kao što su sinoni$\mathrm{mi}$, širi kontekst te informacije o čestoj i specifičnoj upotrebi.

U digitalnom su dobu prostorna ograničenja prevladana, ali pred leksikografima su sada drukčiji izazovi, poput rastućeg fokusa na korisnika i predviđanje mogućih potreba (engl. user-driven situations; vidi FuertesOlivera 2012) te pitanja što rječnik pruža u odnosu na brojne mrežne slobodno dostupne tražilice i baze podataka. ${ }^{8}$ Rječnici stoga moraju pružiti više, odnosno ono što se ne može dobiti samo pretragom interneta. Tehni-

7 Aarhuška je škola osnovana 1996. na Sveučilištu u Aarhusu u Danskoj, u sklopu kojeg postoji Centar za leksikografiju na čelu s Henningom Bergenholtzom. Zastupaju funkcionalnu teoriju leksikografije smatrajući je dijelom informacijskih znanosti, fokusirajući se na različite funkcije rječnika (Bergenholtz-Nielsen-Tarp 2009).

8 Za usporedbu informacija koje se o frazemima daju na internetskim stranicama i u rječnicima vidi Moon 2015. 
ke pokazivanja i pretraživanja podataka u rječniku mogu biti vrlo sofisticirane, ali korisnici koji pripadaju elektroničkoj kulturi 21. stoljeća bez poteškoća prihvaćaju i koriste tematsku organizaciju i složenije mreže uputnica u traganju za riječima kojima bi najbolje mogli izraziti neku ideju.

Upravo zbog veće mogućnosti i fleksibilnosti u prikazu sadržaja, e-rječnici uključuju neku vrstu konceptualnog ustroja. Tako mrežni jednojezični engleski rječnici, koji su svi namijenjeni učenicima engleskoga kao stranoga jezika, imaju ugrađen tezaurus (npr. Cambridge English Dictionary, Collins English Dictionary i Macmillan Dictionary) ili sadrže posebne tematske odjeljke koji korisnicima daju temeljni vokabular iz pojedinih područja. Na primjer, mrežna stranica Oxford Learner's Dictionaries sadrži tzv. minirječnike organizirane u 24 teme. Mrežni rječnik Longman Dictionary of Contemporary English Online na naslovnoj stranici ima odjeljak pod nazivom popularne teme (engl. Hot Topics), a unutar svake se od njih nalaze značenjski povezane riječi i višerječnice, među kojima je i strukovno nazivlje. Zahvaljujući naprednim tehnologijama i specijalizirani rječnici - uključujući i frazeološke - korisnicima pružaju višestruke mogućnosti pristupa podacima. Na primjer, višejezični (englesko-njemačko-francuski) erječnik nogometnog nazivlja Kicktionary ${ }^{9}$ moguće je pretraživati na nekoliko načina: abecedno, po scenama te po hijerarhijskim konceptima, uz mogućnost audioinačice primjera upotrebe te paralelnog pregleda natuknice u trima jezicima (vidi Schmidt 2007, 2009). Mjestom frazeologije u specijaliziranim e-rječnicima bave se neki od najznačajnijih projekata u tom području, poput rječnika znanstvenog diskursa The Louvain EAP dictionary (LEAD) (Granger-Paquot 2010, 2015) ili baze znanstvenih termina i frazema The ARTES bilingual LSP dictionary (Pecman i dr. 2010; Kübler-Pecman 2012), koji također pružaju uvid u riječi putem značenja. Povezivanje riječi prema specifičnim aspektima značenja omogućava korisniku jednostavno prelaženje s jedne riječi ili višerječnice na drugu s kojom je značenjski bliska, ili pak da ekstrahira čitavu skupinu značenjski povezanih riječi ili višerječnica na temelju određenog kriterija.

Frazemi oduvijek spadaju među izazove za leksikografiju, a jedan je od najsloženijih njihova konceptualna organizacija. Pri toj vrsti leksikografske obrade javlja se opće pitanje kriterija po kojima se frazemi grupiraju $\mathrm{u}$ značenjske odnosno tematske skupine te specifično pitanje njihove prezentacije u rječniku. Spomenuli smo da rječnici engleskoga i ruskoga jezika nude različite načine konceptualne organizacije frazeološke građe, a oni su primjer dobre leksikografske prakse. $\mathrm{O}$ tome će više riječi biti u sljedećem odjeljku.

9 http://www.kicktionary.de/ 


\section{Konceptualni ustroj frazeološke građe u rječnicima engleskoga i ruskoga jezika}

U leksikografiji ruskoga i engleskoga jezika nalazimo specijalizirane tiskane rječnike u kojima je frazeološka građa organizirana isključivo konceptualno ili kao kombinacija abecednog i konceptualnog ustroja. Tako je, na primjer, u Rječniku frazeoloških sinonima ruskoga jezika (Bierich-Mokienko-Stepanova 2001) temelj organizacije građe dominanta (rus. croвo доминанта), poput STARAC, TUĆI (ISTUĆI), LUKAV i PUNO, a unutar natuknice frazemi su grupirani u podskupine prema stupnju udaljenosti značenja od centra prema periferiji. Na primjer, pod BOJATI SE navode se tri značenja: 'o osjećaju straha' (što se izražava frazemom mpyca праздновать 'trtariti'), 'о snažnom, paničnom strahu od koga' (npr. бояться как черт ладана 'bojati se kao crnog vraga koga') i ‘o fizičkom stanju kod straha' (npr. душа ушла в пятки 'srce je sišlo u pete komu'). U tematskim frazeološkim rječnicima engleskoga i ruskoga jezika jezične jedinice unutar pojedinih tema navode se abecednim redom (Spears 1998; Lebedeva 2011). ${ }^{10} \mathrm{~S}$ druge strane, abecedno ustrojeni frazeološki rječnici engleskoga jezika ujedno sadrže posebne odjeljke s frazemima grupiranim u zajedničke teme, na primjer ljubav, iskrenost $i$ otvorenost, obmana, neslaganje, uspjeh i neuspjeh, napredak, sreća i tuga (Collins COBUILD Idioms Dictionary 2002; Cambridge Idioms Dictionary 2006) odnosno u tim se odjeljcima frazemi grupiraju oko riječi koje odražavaju određene koncepte (engl. concept words), npr. problem, razumjeti, lako, teško (Longman Idioms Dictionary 1998).

Kad je riječ o specifičnoj organizaciji frazema unutar tema, engleski frazeološki rječnici nude različita rješenja. Tako Collinsov frazeološki rječnik sadrži 32 tematska odjeljka i ima vrlo široku konceptualnu organizaciju pa se unutar pojedine teme navode svi frazemi koji su s njome povezani (na primjer, tema poteškoće sadrži 96 frazema). ${ }^{11} \mathrm{~S}$ druge strane, Longmanov frazeološki rječnik sadrži samo 10 riječi koje odražavaju određene koncepte, ali unutar njih frazemi su grupirani u značenjske podskupine, a svaka

10 Osim tematskih frazeoloških rječnika, za engleski jezik postoje i posebni priručnici za učenje frazema namijenjeni učenicima engleskoga kao stranoga jezika (npr. Goodale 1995; Wright 1999; O’Dell-McCarthy 2010). U njima su frazemi grupirani prema nekom zajedničkom obilježju kao što su tema, konceptualna metafora (npr. VRIJEME JE NOVAC, ZNANJE JE GLEDANJE) ili izvorna domena (npr. frazemi u čijem su sastavu riječi koje se odnose na dijelove tijela, hranu itd.). Pritom frazemi koji su zajedno grupirani nisu nužno i značenjski povezani (to se osobito odnosi na one čije sastavnice pripadaju određenoj izvornoj domeni).

11 Slično tome, Tematski rječnik američkih frazema (Spears 1998) ima ukupno 900 tema, a u nekima se navodi i više od 30 frazema. 
izražava neki specifičan aspekt danoga koncepta. Pritom se unutar pojedine podskupine bilježe najmanje dva, a najviše 16 frazema. Na primjer, pod RAZUMJETI nalazimo sedam značenja, među kojima su 'lako je razumjeti što' s frazemima as plain/clear as day i as plain as the nose on your face (oba u značenju 'jasno kao dan') i 'odjednom shvatiti' s frazemima it dawned on sb, the penny drops (oba u značenju 'sinulo je komu') te see the light 'prosvijetlila se pamet komu'. Slično tome, Cambridgeov frazeološki rječnik unutar pojedine teme frazeme grupira u značenjske podskupine. Tako pod temom ljutnja nalazimo pet značenja: 'biti loše volje', 'biti ljutit', 'živcirati koga', 'jako naljutiti koga' i 'izgubiti živce'.

Za engleski i ruski jezik trenutno ne postoje jednojezični mrežni frazeološki rječnici, ${ }^{12}$ ali zato opći mrežni rječnici engleskoga jezika s ugrađenim tezaurusima uključuju podatke o značenjskoj i konceptualnoj povezanosti riječi i višerječnica. Jedan je takav primjer leksikografska obrada imenice corner ('kut') koja se javlja kao sastavnica frazema in a (tight) corner (dosl. biti u (uskom) kutu 'biti u škripcu'). Cambridge English Dictionary povezuje frazem be in a tight corner ('biti u teškoj situaciji') s drugim srodnim leksemima i frazemima temom imati poteškoća, kojoj korisnik može pristupiti putem poveznice istraži tezaurus (naznačeno je da tezaurus pokazuje sinonime, srodne riječi i fraze koje se odnose na određenu temu). Unutar teme imati poteškoća višerječnice srodnih značenja imaju oznaku frazem (engl. idiom), a to su izrazi poput be (caught) between a rock and a hard place ('biti između čekića i nakovnja'), be in hot water ('biti u gabuli') i have your back tolagainst the wall ('naći se pred zidom'). Macmillan Dictionary u tezaurusu bilježi izraz tight corner (dosl. uzak kut 'teška situacija') i njegovu inačicu back/force someone into a corner (dosl. stjerati u kut koga 'dovesti u tešku situaciju koga') pod temom teške situacije i iskustva, a u njoj su navedene i druge riječi i višerječnice sličnih značenja. Putem poveznica korisnik u tezaurusu ujedno može pretražiti srodne koncepte, na primjer $u$ teškoj situaciji (gdje se bilježi frazem in hot water), biti ili dospjeti u tešku situaciju (gdje se nalaze frazemi be (caught/stuck) between a rock and a hard place i have your back to the wall), opasne ili uzbudljive situacije i zbunjujuće situacije. Iz toga je vidljivo da Cambridgeov rječnik ima razmjerno široku konceptualnu organizaciju kad je riječ o srodnim frazemima, a Macmillan Dictionary nešto specifičniju te se u njemu ujedno povezuju srodni koncepti (npr. teške situacije i opasne situacije).

12 Od jednojezičnih frazeoloških rječnika na internetu je dostupna digitalizirana verzija rječnika slovenskih frazema Janeza Kebera (Slovar slovenskih frazemov). Slobodno dohvatljivo na https://fran.si/192/janez-keber-frazeoloski-slovar-slovenskega-jezika. 
Kad govorimo o organizaciji frazeološke građe $\mathrm{u}$ jednojezičnim rječnicima hrvatskoga jezika, postojeći tiskani frazeološki rječnici imaju samo abecedni poredak. Među tiskanim općim rječnicima konceptualnu organizaciju ima Rječnik sinonima hrvatskoga jezika (Šarić-Wittschen 2008), koji bilježi i frazeme (npr. pod natuknicom lud nalazimo frazeme najeo se ludih gljiva, nisu mu svi kotači u glavi/na mjestu, nije pri zdravoj pameti). Kad je riječ o mrežnim izvorima, za sada jedina mrežna rječnička baza Hrvatski jezični portal nema ugrađen tezaurus, a dvije mrežne leksičke baze koje sadrže višerječnice, Baza frazema hrvatskoga jezika i Kolokacijska baza hrvatskoga jezika, ${ }^{13}$ također su organizirane isključivo abecedno. Dodatan je problem taj što u bazi frazema nema objašnjenja značenja niti primjera upotrebe.

U mrežnome Frazeološkom rječniku hrvatskoga jezika koji je u izradi građa je i konceptualno ustrojena jer smatramo da su za razumijevanje frazema važne konceptualne karakteristike koje oni međusobno dijele. Također, smatramo da korisniku treba omogućiti uvid u to kako može izraziti svoje ideje rabeći figurativni jezik. Budući da u rječniku trenutno ne postoji mogućnost organizacije frazeološke građe $u$ tematske odjeljke (slično ugrađenom tezaurusu u općim mrežnim rječnicima engleskoga jezika), konceptualna organizacija provodi se tako da se na kraju natuknice za pojedini frazem bilježe jedinice srodnih značenja - bliskoznačnice i(li) antonimi - kojima korisnik može pristupiti putem poveznica. U tom se rječniku frazemi mogu pronaći pretraživanjem bilo koje sastavnice, a svaka je natuknica zasebna cjelina povezana s drugima kroz konceptualni ustroj. Temeljno pitanje koje se javlja pri konceptualnoj organizaciji frazeološke građe tiče se kriterija po kojima treba grupirati značenjski srodne frazeme. Iz toga ujedno proizlazi i pitanje koliko frazema treba uključiti unutar pojedine značenjske skupine. U sljedećem odjeljku pobliže ćemo opisati metodologiju i kriterije grupiranja značenjski povezanih frazema te na primjerima pokazati mogućnosti njihove konceptualne organizacije.

\section{Konceptualna organizacija frazema u mrežnome Frazeološkom rječniku hrvatskoga jezika}

Jedan od kriterija po kojem se frazemi grupiraju u ovome rječniku jesu zajednički značenjski i konstrukcijski elementi (Filipović Petrović - Parizoska 2017). To je u skladu s dosadašnjim frazeološkim istraživanjima hrvatskoga i nekih drugih europskih jezika koja su pokazala da struktura doprinosi značenju frazema kao cjeline. Jedan je takav primjer prijedlog

13 Slobodno dohvatljivo na http://frazemi.ihjj.hr/ odnosno http://ihjj.hr/kolokaci$\mathrm{je} / /$. 
$u$, koji odražava konceptualizaciju nekog entiteta kao SPREMNIKA (LakoffJohnson 1980:29-32; Rudzka-Ostyn 2003; Šarić 2008), pa se u frazemima s tim prijedlogom kao sastavnicom situacije i stanja metaforički strukturiraju kao spremnici, npr. biti u klopci, doći u proi plan, pasti u komu, upasti u dugove, baciti u drugi plan koga itd. (vidi Parizoska 2009; Parizoska-Novoselec 2010)..${ }^{14}$ Pritom lokativna konstrukcija označava položaj entiteta na nekom mjestu (npr. biti u klopci), a akuzativna konstrukcija kretanje prema cilju (npr. doći u proi plan). Drugi su primjer poredbeni frazemi. S obzirom na to javlja li se kao tertium comparationis pridjev ili glagol, poredbeni frazem opisuje neko svojstvo (npr. crven kao paprika, blijed kao krpa) odnosno proces, na primjer raditi kao konj, pušiti kao Turčin (vidi Parizoska - Filipović Petrović 2017; Parizoska 2018). Za konceptualnu organizaciju frazema u ovome rječniku drugi je važan kriterij upotreba. ${ }^{15}$ Na temelju podataka iz mrežnoga korpusa hrWaC $(1,2 \text { milijarde riječi; verzija } 2.2)^{16}$ o tipičnom kolokacijskom okruženju pojedinih frazema i kontekstima u kojima se javljaju možemo utvrditi imaju li određeni izrazi zajedničke značenjske i uporabne elemente (pa se, na primjer, odnose na istu vrstu entiteta). Na temelju tih triju kriterija - značenje, struktura i upotreba - frazemi u mrežnome Frazeološkom rječniku hrvatskoga jezika grupiraju se u skupine s konceptualnim uređenjem. U nastavku ćemo na primjerima pokazati načine konceptualnog ustroja u rječniku.

Prvi je primjer frazem ima na bacanje (na lopate) koga, čega u značenju 'ima mnogo koga, čega'. On je u rječniku povezan s bliskoznačnicama ima kao u priči koga, čega i ima kao pljeve (blata) koga, čega te s antonimom nema ni za lijek koga, čega. Korpusni podaci pokazuju da se sva četiri frazema upotrebljavaju s imenicama koje znače neživo (npr. kulinarskih emisija ima na bacanje; mjesta ima kao u priči; posla nema ni za lijek) i s imenicama koje označavaju osobe (npr. ekonomista ima kao pljeve; kupaca nema ni za lijek) ili se metonimijski odnose na osobe (talenata ima na lopate).

Neki frazemi imaju slična značenja, ali se odnose na različite entitete. Jedan su takav primjer poredbeni frazemi čist kao kristal i čist kao suza. Kad

14 Konceptualizacija situacija i stanja kao SPREMNIKA univerzalne je naravi pa je nalazimo u različitim jezicima. Na primjer, u engleskome je odražavaju frazemi s prijedlogom in(to), poput be in hot water (dosl. biti u vrućoj vodi 'biti u gabuli') i back someone into a corner (dosl. stjerati u kut koga 'dovesti u škripac koga').

15 Izrada ovoga rječnika temelji se na uporabnome modelu jezika (engl. usagebased model; Langacker 1988, 2000) koji se zalaže za proučavanje jezika na temelju stvarne upotrebe. U tome se modelu smatra da je jezik u upotrebi najbolji način za utvrđivanje karakteristika jezičnih sustava i njihova ustroja (Kemmer-Barlow 2000: $\mathrm{xV})$.

16 Više o hrWaCu vidi Ljubešić-Klubička (2014). 
se upotrebljavaju u značenju 'sasvim čist', njihovi imenski kolokati imaju slične referente: tipično je riječ o bistroj vodi i nebu bez oblaka. Drugo je značenje tih frazema različito, što je vidljivo i iz činjenice da se upotrebljavaju s različitim vrstama imenica. Tako frazem čist kao kristal ima značenje 'bez ičeg suvišnog' te se tipično odnosi na zvuk bez šumova, na primjer u rečenici Njen nastup je siguran, smion, njena dikcija čista kao kristal. S druge strane, frazem čist kao suza upotrebljava se za osobe visokih moralnih kvaliteta te apstraktne entitete $\mathrm{u}$ značenju 'pošten, častan', kao u rečenici Pobjeda Barcelone je čista kao suza. Među nekim frazemima koji odražavaju isti koncept postoje manje razlike $\mathrm{u}$ frazeološkom značenju. Tako koncept LAGATI povezuje frazeme laže koliko je dug i širok tko, lagati i mazati, lagati kao pas i laže čim zine tko. Kad je riječ o specifičnome značenju, izraze laže koliko je dug i širok tko i lagati i mazati možemo interpretirati kao 'mnogo, pretjerano lagati', lagati kao pas kao 'jako, besramno lagati', a laže čim zine tko kao 'uvijek laže tko'. Sve navedeno znači da će se u rječniku kod tih frazema javiti poveznica na druge kako bi se pokazalo da postoji međusobna sličnost, a razlike će se vidjeti u pojedinim natuknicama u opisu značenja i primjerima. Na slici 1 može se vidjeti leksikografska obrada frazema lagati kao pas sa značenjem i primjerima upotrebe te lista značenjski srodnih frazema čiji su natuknički likovi uređeni kao hipertekst, što znači da se odabirom pojedinoga od njih otvara natuknica i leksikografska obrada odabranog frazema.

lagati kao pas

jako, besramno lagati

Svatko tko vam kaže da je u mjesec dana skinuo 10 kila ili laže ko pas ili se uništava.

Nisi smija govorit o Hrvatskoj? Lažeš ka pas. More jedino bit da nisi TIJA.

\section{Usporedi:}

lagati i mazati

laže čim zine tko

laže koliko je dug i širok tko

Slika 1. Natuknica lagati kao pas s poveznicama na značenjski srodne frazeme u Frazeološkome rječniku hrvatskoga jezika

U prethodnim je slučajevima riječ o manjem broju izraza (do najviše četiri) pa se na kraju natuknice navode svi frazemi koji su značenjski povezani s onim u natukničkome liku. S druge strane, neki se koncepti izraža- 
vaju većim brojem frazema, pa se stoga u rječniku zajedno grupiraju izrazi koji odražavaju određeni aspekt danoga koncepta i imaju slične strukturne karakteristike. Na primjer, teška situacija u hrvatskome se konceptualizira kao stanje u kojem se nalazi neki entitet ili kao događaj u kojem jedan sudionik energijom djeluje na drugoga. Na tome se temelji grupiranje frazema u skupine. Tako jednu skupinu čine frazemi koji su po strukturi lokativne konstrukcije, a upotrebljavaju se u značenju 'biti u neprilici, naći se u teškoj situaciji': biti u banani, biti u frci, biti u govnima (do grla, guše), biti na mukama (na sto muka), biti u gabuli, biti u škripcu, naći se na vjetrometini i naći se u neobranom (nebranom) grožđu. Isti koncept odražavaju i tri frazema koji imaju značenje 'naći se u bezizlaznoj situaciji' , a to su biti između čekića i nakovnja, naći se između dvije vatre i doći pred zid. Budući da je riječ o frazemima koji odražavaju specifičan aspekt teške situacije (nemogućnost pronalaženja izlaza), oni se grupiraju zasebno. Kao posebna skupina bilježe se i frazemi koji tešku situaciju opisuju kao događaj u kojem agens energijom djeluje na temu, pri čemu dolazi do promjene njezina stanja ili mjesta. Ti su frazemi akuzativne konstrukcije, a upotrebljavaju se u značenju 'dovesti koga u nepriliku, težak položaj': stjerati u kut koga, podmetati klipove (pod noge) komu, dovesti pred zid koga, skuhati kašu komu i uvaliti u kašu koga. Drugim riječima, i unutar istog koncepta u organizaciji frazema potrebne su detaljne informacije koje će korisniku omogućiti bolje razumijevanje i sigurniju upotrebu.

Kod nekih frazema koje povezuje određeni koncept, njegovi se specifični aspekti izražavaju različitim vrstama riječi pa se frazemi grupiraju sukladno tome. Tako frazemi u čijem su sastavu pridjevi i stativni glagoli opisuju određeno svojstvo odnosno stanje nekog entiteta, dok frazemi s glagolima dinamike sile (engl. force dynamics; Talmy 1988, 2000) opisuju događaje. ${ }^{17}$ Takvi su, na primjer, frazemi koji opisuju umnu poremećenost. Frazemi koji odražavaju taj koncept u rječniku se grupiraju u dvije skupine. U jednoj se bilježe izrazi koje povezuje značenje 'nije sasvim normalan' - fali (nedostaje) daska u glavi komu, lud kao kupus (šiba, puška), nisu sve koze (ovce) na broju komu, nisu svi doma (kod kuće) komu, posvađan je s mozgom tko, zreo za ludnicu (psihijatriju, Vrapče). U drugoj su skupini frazemi u značenju 'poludjeti, prestati biti uračunljiv', a to su najesti se ludih gljiva, pomutila se pamet komu, puknuti kao kokica, sići s uma (pameti) i skrenuti (šenuti) pameću. Slično tome, kod frazema koje povezuje koncept LJUTNJA jednu skupinu čine izrazi s pridjevima i nesvršenim glagolima u značenju

17 Kod podjele na stanja i događaje oslanjamo se na opis situacija koji nude Radden i Dirven (2007:177): događaji (engl. events) su dinamične situacije koje uključuju promjenu, a stanja (engl. states) su statične situacije koje ne uključuju promjenu. 
'ljutit' (crven od bijesa, ljut (bijesan) kao pas (ris), kipjeti (pucati, pjeniti se) od bijesa, para ide (izlazi) na uši (iz ušiju) komu), a drugu oni sa svršenim glagolima u značenju 'naljutiti se' (pozelenjeti od bijesa, puknuo je film komu, pao je mrak na oči komu). Na taj se način u konceptualnoj organizaciji rječnika prikazuju i kategorije koje odražavaju različite načine sagledavanja iste situacije, što je u skladu s kognitivnogramatičkom postavkom da leksičke i gramatičke jedinice služe za konstruiranje značenja (engl. construal; Langacker 1987).

\section{Zaključak}

U ovome smo radu prikazali mogućnosti konceptualne organizacije frazema u budućem mrežnome Frazeološkom rječniku hrvatskoga jezika. Pri toj vrsti leksikografske obrade temeljno je pitanje metodologija na temelju koje se u e-rječniku povezuju značenjski srodni frazemi te kriteriji za njihovo grupiranje. Pokazali smo da konceptualna organizacija frazema može biti šira ili uža s obzirom na njihove značenjske i strukturne karakteristike te upotrebu. Među bliskoznačnim frazemima mogu postojati određene razlike u značenju, ali grupiraju se zajedno ako imaju sličnu strukturu i kolokacijsko okruženje te se javljaju u sličnim kontekstima. Konceptualna organizacija frazeološke građe u e-rječniku također je vezana uz broj frazema koji odražavaju neki koncept. To je osobito važno ako se određeni koncept može izraziti pomoću većeg broja frazema, primjerice ljutnja ili teška situacija. U takvim je slučajevima frazeme dobro grupirati u značenjske podskupine koje odražavaju specifične aspekte danoga koncepta, na primjer frazemi koji opisuju svojstvo ('ljutit') odnosno proces ('naljutiti se'), stanje ('biti u teškoj situaciji') odnosno dovođenje koga u neko stanje ('dovesti u tešku situaciju koga'). Na taj način korisnik dobiva informacije ne samo o značenjima frazema već i o njihovim gramatičkim karakteristikama i upotrebi. Kombinirano ustrojstvo mrežnog Frazeološkog rječnika hrvatskoga jezika - mogućnost pretraživanja ne samo po natuknicama već i po značenjskim skupinama - u skladu je sa suvremenom leksikografskom praksom, a novost je u hrvatskoj rječničkoj produkciji.

Kad je riječ o daljnjim mogućnostima konceptualne organizacije frazeoloških rječnika u e-leksikografiji hrvatskoga i drugih europskih jezika, jedna je od njih pretraživanje frazema po tematskim poljima odnosno konceptualnim domenama. To je na tragu tematskih odjeljaka u tiskanim frazeološkim rječnicima engleskoga jezika. Na taj način, ovisno o potrebama, korisnik može naći natuknicu pod kojom se nalazi određeni frazem ili pristupiti popisu konceptualnih domena odnosno frazemima organizirani- 
ma unutar njih prema tematskim skupinama. Ta dva načina pretrage objedinjuju moguće dvojake korisničke potrebe: potrebu za značenjem i potrebu za frazemom.

Još jedan korak dalje u konceptualnoj organizaciji frazeološke građe u e-rječniku bilo bi nešto slično kućicama s metaforama (engl. Metaphor Boxes) u Macmillanovu općem rječniku engleskoga jezika. ${ }^{18}$ One su ustrojene u skladu s Lakoffovom i Johnsonovom teorijom konceptualne metafore (Lakoff-Johnson 1980), a u njima se pokazuje poveznica između pojedinih izvornih i ciljnih domena. Na primjer, pod ljutit daju se dva opisa metaforičkog izražavanja ljutnje: biti ljutit je kao kad ti je vruće ili goriš te izgubiti živce je kao eksplozija. Takva konceptualna organizacija uključuje riječi i višerječnice s metaforičkim značenjem, dakle figurativni jezik općenito. To je osobito važno za učenje stranih jezika jer korisniku pruža informacije o načinima na koji se u danome jeziku metaforički strukturiraju određeni koncepti. U konačnici, to je u skladu s načelom funkcionalne leksikografije da korisniku valja pružiti znanje potrebno za komunikaciju u situaciji u kojoj se nalazi.

Kombiniranjem abecednog i konceptualnog ustrojstva, dokidanjem prostornih ograničenja i nelinearnom hipertekstnom organizacijom rječnika otvorile su se nove mogućnosti za funkcionalnu leksikografiju. Te su mogućnosti posebno važne za frazeološke rječnike. Ipak, potencijalno bogatstvo informacija koje je korisniku u današnje doba moguće ponuditi ujedno pred leksikografa postavlja nove izazove: kako organizirati i prezentirati jezičnu građu tako da se promiče upotreba rječnika u odnosu na slobodno dostupne tražilice i baze na internetu. Smatramo da se to može najbolje postići pristupom koji smo prikazali, a prema kojem konceptualna organizacija izvire iz rječničke obrade podataka na razini koja uzima u obzir specifičnosti frazema i potrebe korisnika.

18 https://www.macmillandictionary.com/learn/metaphor/ 


\section{Literatura}

Atkins, B. T. Sue; Michael Rundell. 2008. The Oxford Guide to Practical Lexicography. Oxford - New York: Oxford University Press.

Béjoint, Henri. 2010. The Lexicography of English. Oxford - New York: Oxford University Press.

Bergenholtz, Henning; Sandro Nielsen; Sven Tarp, ur. 2009. Lexicography at a Crossroads: Dictionaries and Encyclopedias Today, Lexicographical Tools Tomorrow. Bern: Peter Lang.

Filipović Petrović, Ivana. 2018. Kada se sretnu leksikografija i frazeologija: o statusu frazema u rječniku. Zagreb: Srednja Europa.

Filipović Petrović, Ivana; Jelena Parizoska. 2017. Leksikografska obrada frazema s promjenjivom glagolskom sastavnicom u hrvatskome. Jezikoslovlje, 18, 2, 245-278.

Fuertes-Olivera, Pedro A. 2009. The Function Theory of Lexicography and Electronic Dictionaries: WIKTIONARY as a Prototype of Collective Free Multiple-Language Internet Dictionary. Ur. Bergenholtz, Henning; Sandro Nielsen i Sven Tarp. Lexicography at a Crossroads: Dictionaries and Encyclopedias Today, Lexicographical Tools Tomorrow. Bern: Peter Lang, 99-134.

Fuertes-Olivera, Pedro A. 2012. On the usability of free Internet dictionaries for teaching and learning Business English. Ur. Granger, Sylviane; Magali Paquot. Electronic lexicography. Oxford: Oxford University Press, 399-424.

Geeraerts, Dirk. 1989. Principles of monolingual lexicography. Ur. Hausmann, Franz Josef. Wörterbücher. Ein internationales Handbuch zur Lexikographie 1. Berlin: Walter de Gruyter, 287-296.

Granger, Sylviane; Magali Paquot. 2010. The Louvain EAP Dictionary (LEAD). Ur. Dykstra, Anne; Tanneke Schoonheim. Proceedings of the XIV Euralex International Congress. Leeuwarden: Fryske Akademy, 321-326.

Granger, Sylviane; Magali Paquot. 2015. Electronic lexicography goes local: Design and structures of a needs-driven online academic writing aid. Lexicographica, 31, 1, 118-141.

Jackson, Howard. 2002. Lexicography: An Introduction. London - New York: Routledge.

Kemmer, Suzanne; Michael Barlow. 2000. Introduction: A Usage-Based Conception of Language. Ur. Barlow, Michael; Suzanne Kemmer. Usage-Based Models of Language. Stanford: CSLI Publications, vii-xxviii.

Kübler, Natalie; Pecman, Mojca. 2012. The ARTES bilingual LSP dictionary: From collocation to higher order phraseology. Ur. Granger, Sylviane; Magali Paquot. Electronic lexicography. Oxford: Oxford University Press, 187-210. 
Lakoff, George; Mark Johnson. 1980. Metaphors We Live By. Chicago - London: The University of Chicago Press.

Landau, Sidney I. ${ }^{2} 2001$. Dictionaries: The Art and Craft of Lexicography. Cambridge: Cambridge University Press.

Langacker, Ronald W. 1987. Foundations of Cognitive Grammar. Vol. 1: Theoretical Prerequisites. Stanford: Stanford University Press.

Langacker, Ronald W. 1988. A Usage-Based Model. Ur. Rudzka-Ostyn, Brygida. Topics in Cognitive Linguistics. Amsterdam - Philadelphia: John Benjamins, 127-164.

Langacker, Ronald W. 2000. A Dynamic Usage-Based Model. Ur. Barlow, Michael; Suzanne Kemmer. Usage-Based Models of Language. Stanford: CSLI Publications, 1-64.

Leroyer, Patrick. 2007. Bringing corporate dictionary design into accord with corporate image: From words to messages and back again. Ur. Gottlieb, Henrik; Jens Erik Mogensen. Dictionary Visions, Research and Practice. Amsterdam - Philadelphia: John Benjamins, 109-117.

Ljubešić, Nikola; Filip Klubička. 2014. \{bs,hr,sr\}WaC - Web Corpora of Bosnian, Croatian and Serbian. Ur. Bildhauer, Felix; Roland Schäfer. Proceedings of the 9th Web as Corpus Workshop (WaC-9). Stroudsburg: Association for Computational Linguistics, 29-35.

McArthur, Tom. 1986. Worlds of Reference: Lexicography, Learning, and Language from the Clay Tablet to the Computer. Cambridge: Cambridge University Press.

Měchura, Michal. 2017. Introducing Lexonomy: an Open-Source Dictionary Writing and Publishing System. Ur. Kosem, Iztok i dr. Electronic lexicography in the 21st century: Proceedings of eLex 2017 conference. Brno: Lexical Computing, 662-679.

Moon, Rosamund. 2015. Idioms: A View from the Web. International Journal of Lexicography, 28, 3, 318-337.

Nielsen, Sandro; Lise Mourier. 2007. Design of a function-based Internet Accounting Dictionary. Ur. Gottlieb, Henrik; Jens Erik Mogensen. Dictionary Visions, Research and Practice. Amsterdam - Philadelphia, 119-135.

Nikolić-Hoyt, Anja. 2004. Konceptualna leksikografija: prema tezaurusu hrvatskoga jezika. Zagreb: Hrvatska sveučilišna naklada.

Parizoska, Jelena. 2009. Idiom variability in Croatian: the case of the CONTAINER schema. Cognitive Studies, 9, 171-180.

Parizoska, Jelena. 2018. Poredbeni frazemi s vlastitim imenima u hrvatskome - korpusni pristup. Slavistički studii, 18, 139-151.

Parizoska, Jelena; Ivana Filipović Petrović. 2017. Variation of Adjectival Slots in kao ('as') Similes in Croatian: A Cognitive Linguistic Account. 
Ivana Filipović Petrović, Jelena Parizoska: Konceptualna organizacija frazeoloških...

FILOLOGIJA 73(2019), 27-45

Ur. Mitkov, Ruslan. Computational and Corpus-Based Phraseology. Second International Conference, Europhras 2017, London, UK, November 13-14, 2017. Proceedings. Cham: Springer, 348-362.

Parizoska, Jelena; Zvonimir Novoselec. 2010. Predodžbena shema SPREMNIKA u frazeologiji: proi i drugi plan. Ur. Brdar, Mario; Marija Omazić; Višnja Pavičić Takač; Tanja Gradečak-Erdeljić; Gabrijela Buljan. Prostor i vrijeme u jeziku: Jezik u prostoru i vremenu. Zagreb - Osijek: Hrvatsko društvo za primijenjenu lingvistiku, 57-67.

Pecman, Mojca i dr. 2010. Processing collocations in a terminological database based on a cross-disciplinary study of scientific texts. Ur. Granger, Sylviane; Magali Paquot. eLexicography in the 21st Century: New Challenges, new applications. Proceedings of eLex 2009, Louvain-la-Neuve, 22-24 October 2009. Louvain-la-Neuve: Presses universitaires de Louvain, 249-262.

Radden, Günther; René Dirven. 2007. Cognitive English Grammar. Amsterdam - Philadelphia: John Benjamins.

Rudzka-Ostyn, Brygida. 2003. Word Power: Phrasal Verbs and Compounds: A Cognitive Approach. Berlin - New York: Mouton de Gruyter.

Schmidt, Thomas. 2007. The Kicktionary: A Multilingual Resource of the Language of Football. Ur. Rehm, Georg; Andreas Witt; Lothar Lemnitzer. Data Structures for Linguistic Resources and Applications. Tübingen: Gunter Narr Verlag, 189-196.

Schmidt, Thomas. 2009. The Kicktionary - A multilingual lexical resource of football language. Ur. Boas, Hans C. Multilingual FrameNets in Computational Lexicography: Methods and Applications. Berlin - New York: Mouton de Gruyter, 101-134.

Šarić, Ljiljana. 2008. Spatial Concepts in Slavic. A Cognitive Linguistics Study of Prepositions and Cases. Wiesbaden: Harrassowitz Verlag.

Ščerba 1974 = Щерба, Л. В. 1974. Языковая система и речевая деятельность. Денинград: Наука.

Štrkalj Despot, Kristina; Christine Moehrs. 2015. Pogled u e-leksikografiju. Rasprave Instituta za hrvatski jezik i jezikoslovlje, 41, 2, 329-353.

Štrkalj Despot, Kristina i dr. 2019. State-of-the-art on monolingual lexicography for Croatia (Croatian). Slovenščina 2.0, 7, 1, 65-77.

Talmy, Leonard. 1988. Force dynamics in language and cognition. Cognitive Science, 12, 49-100.

Talmy, Leonard. 2000. Toward a cognitive semantics. Volume I: Concept structuring systems. Cambridge, Mass.: MIT Press. 


\section{Vrela}

Baranov i Dobrovol'skij 2007 = Баранов А. Н.; Д. О. Добровольский. 2007. Словарь-тезаурус современной русской идиоматики. Москва: Мир энциклопедий Аванта+.

Bendow, Ivana. 2006. Englesko-hrvatski frazeološki rječnik. Zagreb: Školska knjiga.

Bendow, Ivana. 2009. Hrvatsko-engleski frazeološki rječnik. Zagreb: Školska knjiga.

Bierich, Mokienko i Stepanova 2001 = Бирих, А. К.; В. М. Мокиенко; А. И. Степанова. 2001. Словарь фразеологических синонимов русского языка. Москва: Астрель.

Cambridge English Dictionary. https://dictionary.cambridge.org/dictionary/englishl

Cambridge Idioms Dictionary. 2006. Cambridge: Cambridge University Press.

Collins COBUILD Idioms Dictionary. ${ }^{22002 . ~ G l a s g o w: ~ H a r p e r C o l l i n s ~ P u b l i s-~}$ hers.

Collins English Dictionary. https://www.collinsdictionary.com/dictionary/english

Goodale, Malcolm. 1995. Collins COBUILD Idioms Workbook. London: HarperCollins Publishers.

Lebedeva 2011 = Дебедева, А. А. 2011. Устойчивые сравнения русского языка: краткий тематический словарь. Москва: Фдинта.

Longman Dictionary of Contemporary English Online: LDOCE. https://www. ldoceonline.com/

Longman Idioms Dictionary. 1998. Harlow: Longman.

Macmillan Dictionary. https://www.macmillandictionary.com/

Matešić, Josip. 1982. Frazeološki rječnik hrvatskoga ili srpskog jezika. Zagreb: Školska knjiga.

Menac, Antica; Željka Fink Arsovski; Radomir Venturin. 2003. Hrvatski frazeološki rječnik. Zagreb: Naklada Ljevak.

Menac, Antica; Željka Fink Arsovski; Radomir Venturin. 2014. Hrvatski frazeološki rječnik. Zagreb: Naklada Ljevak.

O'Dell, Felicity; Michael McCarthy. 2010. English Idioms in Use Advanced. Cambridge: Cambridge University Press.

Ogoljcev 2001 = Огольцев В. М. 2001. Словарь устойчивых сравнений русского языка. Москва: Астрель.

Oxford Learner's Dictionaries. https://www.oxfordlearnersdictionaries.com/topicl 
Spears, Richard A. 1998. NTC's Thematic Dictionary of American Idioms. Lincolnwood (Chicago): NTC Publishing Group.

Šarić, Ljiljana; Wiebke Wittschen. 2008. Rječnik sinonima hrvatskoga jezika. Zagreb: Jesenski i Turk.

Wright, Jon. 1999. Idioms Organiser: Organised by metaphor, topic and key word. Hove: LTP.

\title{
Conceptual organization of idioms dictionaries in e-lexicography
}

\begin{abstract}
Monolingual dictionaries of Croatian idioms are organized alphabetically, whereas dictionaries of other European languages, including English and Russian dictionaries, may be organized conceptually and contain sections where idioms are grouped into themes. With the advent of e-lexicography, new organizational paradigms have become available, which is why conceptual organization is applied in online dictionaries. As online dictionaries are not spatially constrained, the conceptual organization of idiomatic expressions raises questions as to the criteria which should be applied when linking idioms with similar meanings and as to the number of items which should be listed under individual themes.

The aim of this paper is to explore the possibilities of organizing material in the Online Dictionary of Croatian Idioms (under development), which includes conceptual organization. More specifically, we will show that the grouping may vary: idioms may be arranged more widely according to concept or more narrowly according to idiomatic meaning. In this way we will explore the advantages and disadvantages of the principles of organizing idioms in online dictionaries.
\end{abstract}

Ključne riječi: frazeološki rječnici, konceptualna organizacija, e-leksikografija, hrvatski jezik

Keywords: dictionaries of idioms, conceptual organization, e-lexicography, Croatian 
